\title{
Evaluation of Factors Influencing the Biomass of Soil Microorganisms and DNA Content
}

\author{
Wolińska Agnieszka, Stępniewska Zofia, Bułaś Aleksandra, Banach Artur \\ Department of Biochemistry and Environmental Chemistry, Institute of Biotechnology, The John Paul II Catholic University, Lublin, \\ Poland. \\ Email: awolin@kul.lublin.pl
}

Received November $10^{\text {th }}, 2011$; revised December $14^{\text {th }}, 2011$; accepted December $28^{\text {th }}, 2011$

\begin{abstract}
The aim of the study was the statistical evaluation of the impact of water potential (pF), oxygen availability (ODR) and the way of land use on microbial biomass (MB) and soil DNA content. Soil was extracted from the surface $(0-20 \mathrm{~cm})$ and subsurface $(20-40 \mathrm{~cm})$ layers of Mollic Gleysol. Soil material was collected in July 2009 from the village Kosiorów (SE part of Poland), from the two distinct neighbouring areas: agriculturally exploited (AE), and fallow land (FL), which served as the control area. Moisture content was determined for a range of $\mathrm{pF}$ values $(0,1.0,1.5,2.0)$, which corresponded to availability of water usable by microorganisms and plant roots. Finally, our results revealed significant $(p<0.001)$ positive relationship between DNA and soil MB content, and negative correlations between soil MB and both $\mathrm{pF}$ and ODR. Importantly, MB seemed significantly dependent on the different way of land use, and higher MB content was noted in the soil agriculturally exploited $(p<0.05)$ in contrast to the control area.
\end{abstract}

Keywords: Microbial Biomass; Soil DNA; Water Potential; Agricultural Activity

\section{Introduction}

The term of microbial biomass is commonly used to describe the total mass of microorganisms present in soil [1]. The importance of the MB in soil functioning is well recognised [2]. Moreover, MB as an integrative measure of the physiologically active part of the soil microflora is recommended by 8 countries of European Union (e.g., Germany, United Kingdom, Austria, Switzerland), as important factor of soil quality, which is included in soil microbial degradation monitoring program [3].

Soil MB is also considered to be a useful criterion for an early indication of environmental stress $[1,4]$ as variability in microbial communities can precede detectable changes in soil properties. An example is the turnover rate of the MB, which is much faster and takes, e.g., 1 - 5 years, than the turnover rate of total soil organic matter [5]. It is partly due to the large pool of relatively inactive and dormant microorganisms, having the potential to reflect the past [6]. Life in the soil environment is constantly influenced by drying and rewetting cycles, as soils are continually exposed to rainfall, wind and snow [7]. A part of the microbial population dies during each drying-andwetting cycle resulting in the fluctuation of soil microbial composition [8]. Soil water content as a function of the soil water tension is described by $\mathrm{pF}$ curve, which provides information about the ability for water retaining by the soil pores at any given water tension, or conversely, how tightly a water is held between soil aggregates [9]. Therefore, also soil aeration status is strongly depended from $\mathrm{pF}$ values. It has been also shown experimentally, that ODR factor satisfactorily reflects the supply of oxygen to the plant roots [10,11]. Oxygen availability is among the most important factors affecting soil microbial activeties [12]. There is a specific gas demand for different soil microbes including bacteria, fungi, and other microorganisms [7]. ODR is affected by several factors. It increases with reducing soil water content or increasing suction up to a certain level and then declines with further depletion of water [13]. Soil environment is the major reservoir of microbial genetic diversity and thus should be particularly protected. The breakthrough in soil biology was the discovery of DNA, which is a carrier of biological information and the best characteristics of every organism. Thus, soil DNA analysis is considered to be important and precise tool towards a better recognition of soil microbial functionality and interrelationships among them.

The size of MB was found to be strongly correlated with content of base cations, base saturation, cation exchange capacity, and organic matter quality [14], as well as with soil bulk density, nutrient contents and phosphatase and invertase activities [15]. However, there is a lack of studies on relationships between MB and such important soil factors like $\mathrm{pF}$ or ODR, what may be decisive 
for the course of processes responsible for plant development, and soil fertility. Investigation of the effect of human agricultural activity on MB content is also interesting part of the current study. Thus, the aim of the work was the statistical description of the impact of $\mathrm{pF}$, ODR, and human agricultural activities on MB and DNA content in soil.

\section{Material and Method}

\subsection{Soil and Investigated Area Description}

The soil used in the experiment was Mollic Gleysol (Table 1). Soil was sampled in July 2009 from the village Kosiorów, situated in the Wilków community (SE part of Poland) from depths of $0-20$ and $20-40 \mathrm{~cm}$. To make possible an estimation of the effect of different way of land use on MB, soil samples were collected from two neighbouring plots: one of them was agriculturally exploited with systematic fertilization and pasturage (under human activity), whilst the other one was classified as fallow land and used as a control area (without any human impact).

\subsection{Assaying of Soil Retention Curves}

The instrument used for determining water retention curves was a steel pressure chamber, inside of which a porous plate saturated with water was located. At the bottom, soil samples, continuously exposed to atmospheric pressure, make the hydraulic contact with the porous plate [16]. The chamber was closed and the desired air pressure $P$ was applied, driving away the soil water retained at pressures below $P$, until equilibrium was reached [16]. Soil samples were collected using plastic containers and placed in an airtight chamber (for 10 days), part of a laboratory set LAB o12 (Soil Moisture Equipment Company, USA), before a pressure was applied. The moisture content was determined via the drying process, for the range of water potentials $(0,1.0,1.5$ and $2.0 \mathrm{pF})$, corresponding to availability of water usable by microorganisms and plant roots.

\subsection{ODR Measurement}

After determination of proper $\mathrm{pF}$ values, ODR was measured by ODR-meter manufactured by the Institute of
Agrophysics, Polish Academy of Soil Sciences (Lublin), using Malicki and Bieganowski [17] method. The ODR technique consists of the measurement of the electric current intensity corresponding to the reduction of oxygen on a platinum cathode placed in the soil and negatively polarized with respect to the reference electrode (calomel). As oxygen is consumed at the microelectrode, more oxygen needs to diffuse radially to the electrode in response to the accumulated gradient. This is analogous to oxygen consumption by respiration of root surface or by microbial respiration. Four platinum wire electrodes $(0.5 \mathrm{~mm} \times$ $4 \mathrm{~mm}$ ) were placed at the depth of $2 \mathrm{~cm}$ and polarized to $-0.65 \mathrm{~V}$ versus saturated calomel electrode for $4 \mathrm{~min}$. The data were recorded in three replicates, for each sample.

\subsection{Microbial Biomass}

Soil MB was determined by a fumigation-extraction method using $\mathrm{CHCl}_{3}$ as an agent responsible for the cellular death of microorganisms, according to Joregensen [18] procedure. Concentration of head-space $\mathrm{CO}_{2}$ released by microorganisms which survived incubation with $\mathrm{CHCl}_{3}$ was measured by a gas chromatograph (Varian CP-3800, equipped with a TCD detector).

\subsection{DNA Extraction}

Soil DNA was extracted from samples at $\mathrm{pF} 0$ (full water capacity conditions) and $\mathrm{pF} 2.0$ (field capacity conditions), using the GeneMatrix soil DNA isolation kit (EURx 1.4, Poland), according to the manufacturer's instructions. This kit was designed specifically for the rapid isolation of pure, humic-free microbial DNA from soil samples, and guaranteed the proper DNA isolation procedure. Concentration of DNA was determined spectrophotometrically at $260 \mathrm{~nm}$ (Shimadzu, UV-1800, Japan).

\subsection{Data Analyses}

Statistical analyses were performed by means of Statistica 8.0 software (STATSOFT, USA). One-way ANOVA test was used to investigate significant $(p<0.05)$ effect of $\mathrm{pF}$, ODR, DNA content on soil MB quantity. Results of the significance differences analyses are presented in Table 2 only. In Figures 1-4 the average values with standard deviations are demonstrated.

Table 1. Basic characteristics of the soil.

\begin{tabular}{|c|c|c|c|c|c|c|c|}
\hline \multirow{2}{*}{ Place } & \multirow{2}{*}{ Depth $(\mathrm{cm})$} & \multicolumn{4}{|c|}{ Granulometric composition (\%, dia in $\mathrm{mm})$} & \multirow{2}{*}{$\mathrm{pH}\left(\mathrm{H}_{2} \mathrm{O}\right)$} & \multirow{2}{*}{ TOC (\%) } \\
\hline & & $1-0.1$ & $0.1-0.02$ & $0.02-0.002$ & $<0.002$ & & \\
\hline \multirow{2}{*}{$\begin{array}{l}\text { Agriculturally exploited } \\
\text { (AE) }\end{array}$} & $0-20$ & 87 & 8 & 3 & 2 & 6.7 & 22.5 \\
\hline & $20-40$ & 90 & 7 & 2 & 1 & 6.4 & 1.4 \\
\hline \multirow{2}{*}{ Fallow land (FL) } & $0-20$ & 91 & 6 & 3 & 0 & 6.2 & 20.1 \\
\hline & $20-40$ & 95 & 3 & 2 & 0 & 6.5 & 1.3 \\
\hline
\end{tabular}


Table 2. Statistically significant relationships between MB and analyzed parameters, $\mathrm{N}=12$.

\begin{tabular}{ccccc}
\hline $\begin{array}{c}\text { Object } \\
\text { investigated }\end{array}$ & Depth $(\mathrm{cm})$ & $\mathrm{pF}$ & ODR & $\mathrm{c} \mathrm{DNA}$ \\
\hline \multirow{2}{*}{$\mathrm{AE}$} & $0-20$ & $-0.68^{*}$ & $-0.20^{\text {n.s. }}$ & $0.97^{* *}$ \\
& $20-40$ & $-0.53^{*}$ & $-0.52^{\text {n.s. }}$ & $0.99^{* * *}$ \\
FL & $0-20$ & $-0.94^{* * *}$ & $-0.83^{* * *}$ & $0.86^{*}$ \\
& $20-40$ & $-0.74^{* *}$ & $-0.59^{*}$ & $0.89^{*}$
\end{tabular}

${ }^{*},{ }^{* *},{ }^{* *}$-indicate significance at the $p<0.05, p<0.01$, and $p<0.001$, respectively; ${ }^{\text {n.s. }}$ - not significant difference.
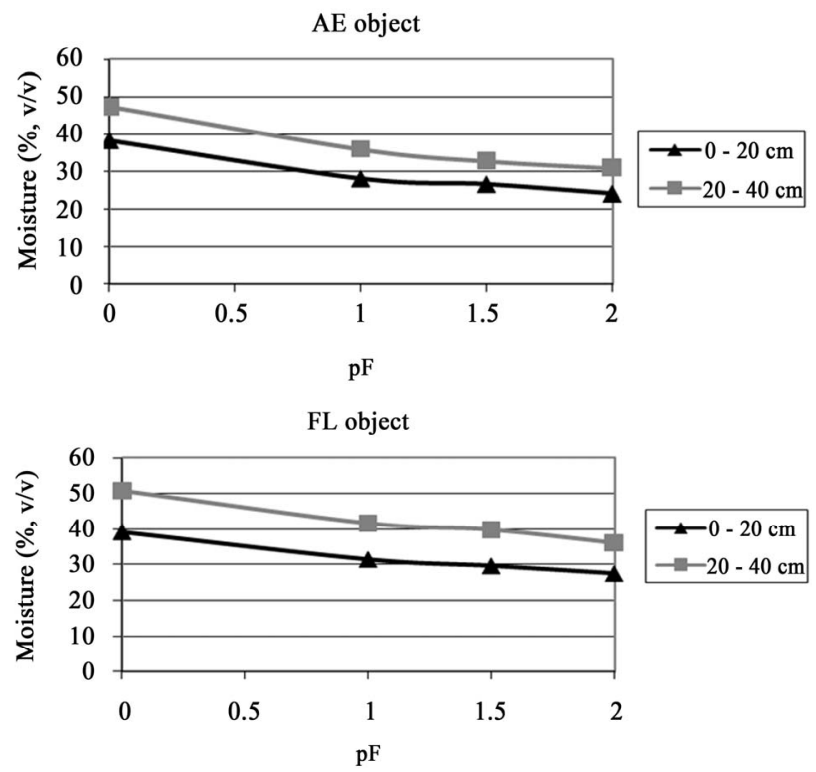

Figure 1. The relationship between soil water content $(\%$ $\mathrm{v} / \mathrm{v})$ and $\mathrm{pF}$ values. The curves are related to two depths $(0$ $20 ; 20-40 \mathrm{~cm}$ ) of the investigated soil areas.
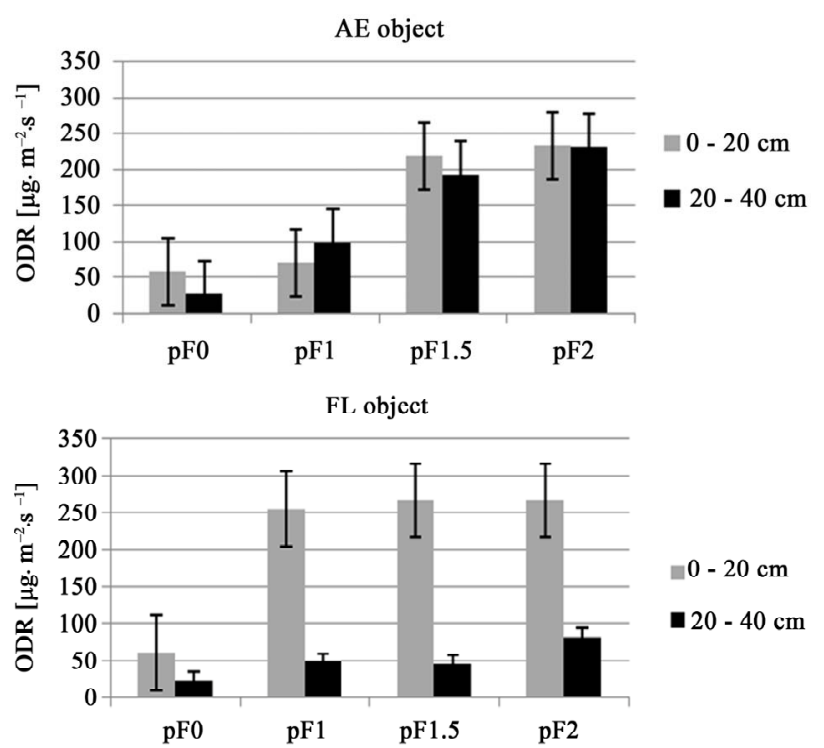

Figure 2. Variability of ODR values as an effect of water potential at two depths of the investigated soil areas. Average values with standard deviations are presented.
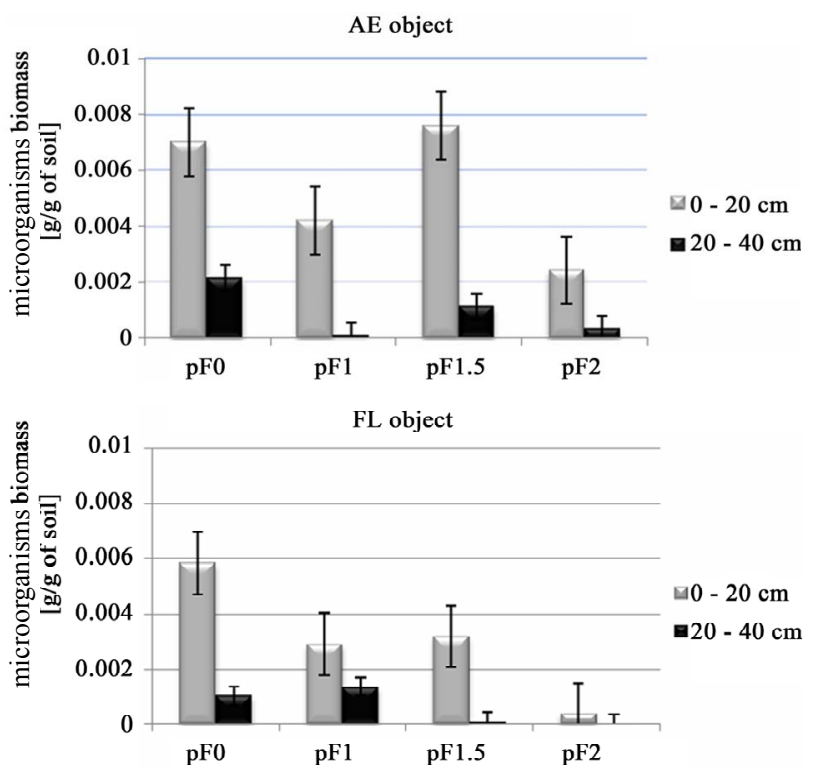

Figure 3. Variability of MB levels as an effect of water potential at two depths of the investigated soil areas. Average values with standard deviations are presented.
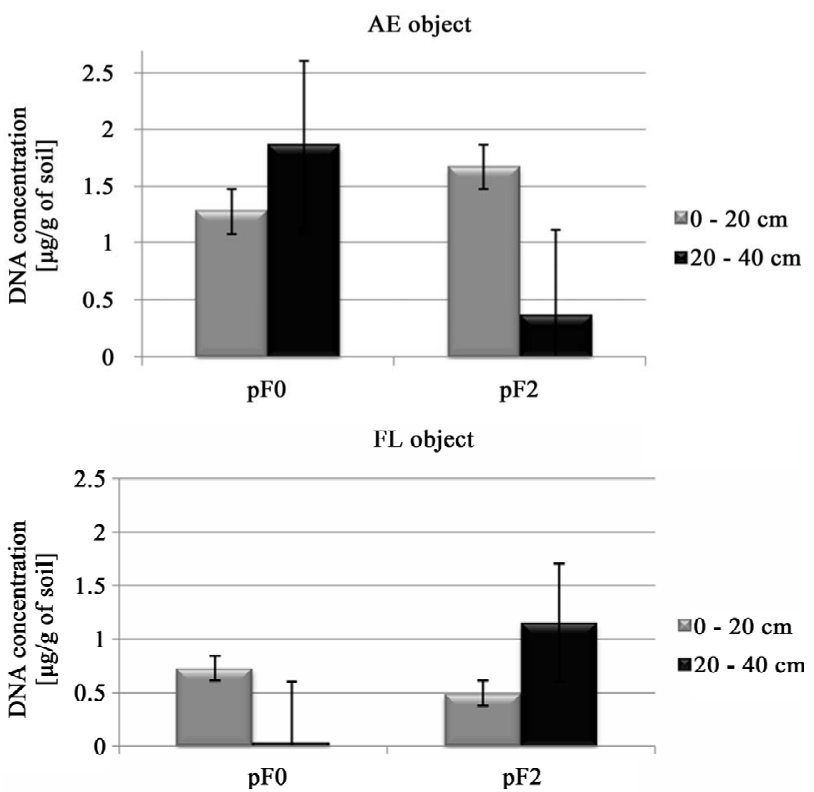

Figure 4. DNA content at two depths of the investigated soil areas as an effect of water potential. Average values with standard deviations are presented.

\section{Results and Discuss}

\subsection{Soil Retention Abilities}

An incubation of the soil samples under different controlled moisture conditions altered significantly ODR, MB and DNA concentration. The relationships between soil water content $(\%, v / v)$ and $\mathrm{pF}$ for the two layers of $\mathrm{Mol}$ lic Gleysol, for both tested areas (AE and FL) are presented in Figure 1. 
Generally, the investigated soils demonstrated similar abilities to retain water, even though soil from the control area (FL) displayed slightly higher (c.a. 3\% more than soil agriculturally exploited) capacity for water keeping. This might be connected with beginning of decay process on $\mathrm{AE}$ object, what resulted in looseness of soil structure and higher intensity of mineralization and humification of the soil organic compounds. Moreover, higher ability of holding water in the subsurface layers were noted, and equalled $34 \%-47 \% \mathrm{v} / \mathrm{v}$ and $41 \%-50 \% \mathrm{v} / \mathrm{v}$ in $\mathrm{AE}$ and FL objects, respectively. Similar capability of Mollic Gleysol for water maintaining was also indicated [19]. The soil-water interactions are greatly or extremely important to soil fertility and therefore are the subject of interest to agricultural engineers and farmers. Furthermore, information about water holding capacity is important for agronomic and hydrologic characteristic of soils. It expresses, how much water can be stored in the soil for plant use during periods without rain or irrigation [20].

This provides an indication of soil sensitivity to drought and could be used to calculate the probability of occurrence of deep drainage or groundwater recharge process. It was also reported that macropore continuity is very important to the aeration status of the soil, thus the effect of soil compaction on other aeration properties depends on soil hydro-physical status $[13,21]$.

\subsection{Oxygen Availability in AE and FL Objects}

Based on the performed measurements it was found, that $\mathrm{pF}$ constitutes a significant factor $(p<0.001)$ determining ODR levels in the soil environment. Soil desiccation, occurring in the direction from $\mathrm{pF} 0$ to $\mathrm{pF} 2.0$, was the reason of stimulation of ODR (Figure 2).

The oxygen availability in relation to the soil water potential indicates, that ODR values at surface layer of AL object fluctuated from 50 to $233 \mu \mathrm{g} \mathrm{O} /\left(\mathrm{m}^{2} \cdot \mathrm{s}\right)$ at $\mathrm{pF} 0$ and $\mathrm{pF} 2.0$, respectively. At deeper layer $(20-40 \mathrm{~cm})$ of agriculturally exploited Mollic Gleysol ODR ranged between 26 till to $240 \mu \mathrm{g} \mathrm{O} /\left(\mathrm{m}^{2} \cdot \mathrm{s}\right)$, for as follows $\mathrm{pF} 0$ and $\mathrm{pF}$ 2.0. Stronger variety of ODR values in the FL object was observed, we noted values between 60 and $266 \mu \mathrm{g}$ $\mathrm{O}_{2} /\left(\mathrm{m}^{2} \cdot \mathrm{s}\right)$ as in the surface layer, whilst in the subsurface $80 \%$ decrease of ODR was found and registered values oscillated from 23 to $81 \mu \mathrm{g} \mathrm{O}_{2} /\left(\mathrm{m}^{2} \cdot \mathrm{s}\right)$, for $\mathrm{pF} 0$ and $\mathrm{pF}$ 2.0 , respectively. We assume that way of land use and sys- tematically applied ploughing at AE object may be the reason of higher ODR level as well in surface as in sub- surface layer. FL on the other hand, despite the fact of comparable level of ODR in surface layer, in the subsur- face was characterized by rapid reduction of oxygen availability, below $35 \mu \mathrm{g} \mathrm{O} /\left(\mathrm{m}^{2} \cdot \mathrm{s}\right)$, which is the minimum level of ODR necessary for proper root growth [11,22]. This might be caused by lack of human agricultural activities, as e.g. ploughing may contribute in soil ventila- tion improvement. On the contrary, [19] Walczak et al. (2001) noted tendency for higher oxygen availability in the deeper layers, rather than in surface of the Mollic Gleysol, whereas [23] Stępniewska et al. (2003) observed analogous trend in the Eutric Cambisol.

It may be caused either by methodical limitations, as the water barriers or water films present on the surface of electrode could be broken off [9], or by the differences in granulometric composition of analyzed soil samples (Table 1), as the fact, that large granulation favourable for forming of aeration pores was noted in the subsurface layers.

\subsection{Soil Microbial Biomass}

Soil MB content was also strongly influenced by $\mathrm{pF}$ conditions and the way of land use (Figure 3). The significantly higher values $(0.0077$ and $0.0058 \mathrm{~g} / \mathrm{g}$ of soil) were stated in the surface layers at full water capacity conditions ( $\mathrm{pF}$ 0) for AL and FL objects, respectively, as compared to the deeper layers of soil. In subsurface layers the reduction of $\mathrm{MB}$ content, c.a. 5 times, was observed.

The highest values of $\mathrm{MB}$ estimations in $\mathrm{AE}$ object were undoubtedly connected with total organic carbon (TOC) content, what favoured the microorganisms' abundance by supplying sources of energy necessary for activity of soil biota and growing crops. This observation is consistent with other studies [24-26]. Registered almost 85\% reduction of $\mathrm{MB}$ in the subsurface layers come out of distribution of microorganisms in the soil profile, since microorganisms are mostly confined to the surface soil layer owing to better aeration and greater nutrient availability. Anthropogenic activities and soil management in particular, are mostly responsible for disturbing the chemico-physical and biological equilibrium of soil [27]. A particularly serious problem is the decrease in the organic matter content of agricultural soils, which may endanger soil fertility and enhance erosion. The MB, as a small fraction of soil organic matter, is a source and sink of nutrients and controls soil organic matter mineralization [27,28] Fisk and Fahey (2001), analogically at current study noted higher content of MB (by $20 \%$ - 30\%) at agricultural areas in response to fertilization, than at fallow ones. Also, other findings pointed out a distinct relationship between soil fertility and soil MB, suggesting that MB measurements provide a valid estimate of soil quality [14,29].

\subsection{DNA Content}

Similarly to MB distribution of DNA concentrations in surface layers were 2 times higher in AE object (Figure 4), than in control soil (not under cultivation) at $\mathrm{pF} 0$. Even more differentiation in subsurface layers were stated, where DNA level reached 12 fold higher values in AE, in 
relation to FL area. The usage of GeneMatrix soil DNA isolation kit let us to receive $0.4-1.8 \mu \mathrm{g} / \mathrm{g}$ and $0.5-1.2$ $\mu \mathrm{g} / \mathrm{g}$ of soil DNA concentrations in AE and FL objects, respectively and revealed that the quality (fragment size and purity) of the extracted DNA was generally very good. However, one should always realize that extraction of DNA from soil samples is never $100 \%$ efficient and can vary from a few $\mu \mathrm{g}$ to almost $200 \mu \mathrm{g}$ DNA per g dry weight of soil. Most of authors, however, reported that the obtained values ranged from 1 to about $50 \mu \mathrm{g}$ of total DNA per g dry weight of soil depending on the method applied and soil sample studied [30,31].

\subsection{Statistical Relationships between Parameters Analyzed}

Statistical relationships between MB and investigated parameters ( $\mathrm{pF}$, ODR, DNA content, way of land use) described by correlations coefficient $(r)$ are presented in Table 2. Significant influence $(p<0.05)$ of tested parameters on $\mathrm{MB}$ was found. The positive relationships between MB and DNA content, and negative correlations between MB and soil physical factors like $\mathrm{pF}$ and ODR were revealed.

Both our and other studies demonstrated that MB can be highly sensitive to environmental factors. Although, study by [32] Singh and Yadava (2006) confirmed negative correlation between $\mathrm{MB}$ and soil moisture, even so prior to our study, rather little attention has been paid to the influence of $\mathrm{pF}$, ODR, DNA content and way of land use on soil MB. Therefore, our work was focused on these relationships and determination of statistical correlations. The positive relationships between MB and DNA content suggest the domination of intercellular DNA form at both $\mathrm{AE}$ and FL objects, and $\mathrm{MB}$ is considered to be a good factor relating to the total mass of microorganisms present in soil. Our results are supported by the findings of [33] Blagodatskaya et al. (2003), who noted that DNA content correlated strongly with the total MB in Paleosol soils from Southern Urals $\left(R^{2}=0.97\right)$, as well as by work of [34] Hartmann et al. (2005), who described analogical correlation $\left(\mathrm{r}=0.91^{* * *}\right)$. Nevertheless, the interpretation of our results has been challenging because of the lack of enough publications in available literature concerning the determination of $r$ coefficients as a goodness of fit between investigated soil factors and MB. However, determined relationships demand further investigations and selection of the other soil types, for better explanation and confirmation of the obtained correlations.

\section{Conclusion}

Importantly, the way of land use significantly $(p<0.05)$ influenced on MB and DNA content, and higher content of MB and DNA concentration were noted in the $\mathrm{AE}(p<$
$0.05)$, in contrast to the FL area. Significant $(p<0.05)$ positive relationships between soil MB and DNA concentration were revealed, whereas $\mathrm{pF}$ and ODR were negatively correlated to MB. Oxygen availability values of $30-255 \mu \mathrm{g} \mathrm{O} / /\left(\mathrm{m}^{2} \cdot \mathrm{s}\right)$ and $20-80 \mu \mathrm{g} \mathrm{O}_{2} /\left(\mathrm{m}^{2} \cdot \mathrm{s}\right)$ in the AE and FL objects, respectively, suggested higher oxygen availability in the subsurface layer of AE area $(p<0.05)$, what might be connected with human agricultural practices, e.g. traditional regular ploughing, which significantly improves soil aeration status.

\section{Acknowledgements}

This work was supported by the IUVENTUS PLUS grant (No IP 2010 001070).

\section{REFERENCES}

[1] K. Broos, M. L. Macdonald, D. A. Heemsbergen, M. B. Barnes, M. Bell and M. J. McLaughlin, "Limitations of Soil Microbial Biomass Carbon as an Indicator of soil Pollution in the Field," Soil Biology and Biochemistry, Vol. 39, No. 10, 2007, pp. 2693-2695.

doi:10.1016/j.soilbio.2007.05.014

[2] E. A. Stockdale and P. C. Brookes, "Detection and Quantification of the Soil Microbial Biomass-Impacts on the Management of Agricultural Soils," The Journal of Agriculture Sciences, Vol. 144, No. 4, 2006, pp. 285-302. doi: $10.1017 / \mathrm{S} 0021859606006228$

[3] A. Winding, K. Hund-Rinke and M. Rutgers, "The use of Microorganisms in Ecological Soil Classification and Assessment Concepts," Ecotoxicology and Environmental Safety, Vol. 62, No. 2, 2005, pp. 230-248.

[4] M. Schloter, O. Dilly and J. C. Munch, "Indicators for Evaluating Soil Quality," Agriculture, Ecosystems and Environment, Vol. 98, No. 1-3, 2003, pp. 255-262. doi:10.1016/S0167-8809(03)00085-9

[5] M. R. Carter, E. G. Gregorich, D. A. Angers, M. H. Beare, G. P. Sparling, D. A. Wardle and R. P. Voroney, "Interpretation of Microbial Biomass Measurements for soil Quality Assessment in Humid Temperate Regions," Canadian Journal of Soil Science, Vol. 79, No. 4, 1999, pp. 507-520. doi:10.4141/S99-012

[6] L. Ranjard, F. Poly and S. Nazaret, "Monitoring complex Bacterial Communities Using Culture-Independent Molecular Techniques: Application to Soil Environment," Research in Microbiology, Vol. 151, No. 3, 2000, pp. 167177. doi:10.1016/S0923-2508(00)00136-4

[7] A. Wolińska and Z. Stępniewska, "Microorganisms Abundance and Dehydrogenase Activity as a Consequence of Soil Reoxidation Process," In: M. Miransari, Ed., Soil Tillage and Microbial Activities, Research Singpost Publisher, Kerala, 2011, pp. 111-143.

[8] R. Daniel, "The Metagenomics of Soil," Nature Reviews Microbiology, Vol. 3, No. 6, 2005, pp. 470-478.

[9] A. Wolińska and R. P. Bennicelli, "Dehydrogenase Activity Response to Soil Reoxidation Process Described as Varied Conditions of Water Potential, Air Porosity and 
Oxygen Availability," Polish Journal of Environmental Studies, Vol. 19, No. 3, 2010, pp. 651-657.

[10] J. Gliński, W. Stępniewski, Z. Stępniewska, T. Włodarczyk and M. Brzezińska, "Characteristics of Aeration Properties of Selected Soil Profiles from Central Europe," International Agrophysics, Vol. 14, No. 1, 2000, pp. 17-31.

[11] W. Stępniewski, Z. Stępniewska, J. Gliński, M. Brzezińska, T. Włodarczyk, G. Przywara, G. Varallay and K. Rajkai, "Dehydrogenase Activity of Some Hungarian Soils as Related to Their Water and Aeration Status," International Agrophysics, Vol. 14, No. 3, 2000, pp. 341-354.

[12] G. L. Hutchinson, "Biosphere-Atmosphere Exchange of Gaseous N Oxides," In: R. Lal, J. Kimble, E. Levine and B. A. Steward, Eds., Soil and Global Change, CRC Lewis Publisher, Boca Raton, 1995, pp. 219-236.

[13] M. Brzezińska, T. Włodarczyk, W. Stępniewski and G. Przywara, "Soil Aeration Status and Catalase Activity," Acta Agrophysica, Vol. 5, No. 3, 2005, pp. 555-565.

[14] J. Zwoliński, "Microbial Biomass versus Soil Fertility in Forest Sites," Polish Journal of Ecology, Vol. 52, No. 4, 2004, pp. 5553-5561.

[15] Z. Z. Jin, J. Q. Lei, X. W. Xu, J. L. Fan, S. F. Zhao, H. W. Zhou and F. Gu, "Relationships of Soil Microbial Biomass with Soil Environmental Factors in Tarim Desert Highway Shelter-Forest," in Chinese, Chinese Journal of Applied Ecology, Vol. 20, No. 1, 2009, pp. 51-57.

[16] L. F. Pires, O. O. S. Bacchi and K. Reichardt, "Soil Water Retention Curve Determined by Gamma-Ray Beam Attenuation," Soil and Tillage Research, Vol. 82, No. 1, 2005, pp. 89-97. doi:10.1016/j.still.2004.06.003

[17] M. A. Malicki and A. Bieganowski, "Chronovoltammetric Determination of Oxygen Flux Density in the Soil," International Agrophysics, Vol. 13, No. 3, 1999, pp. 273281.

[18] R. G. Joergensen, "The Fumigation-Extraction Method to Estimate Soil Microbial Biomass: Calibration of the $\mathrm{k}_{\mathrm{EN}}$ Value," Soil Biology and Biochemistry, Vol. 28, No. 1, 1996, pp. 25-31. doi:10.1016/0038-0717(95)00101-8

[19] R. Walczak, B. Witkowska-Walczak and C. Sławiński, "Water Retention and Conductivity of Polish Mollic Gleysols," in Polish, Acta Agrophysica, Vol. 53, No. 2, 2001, pp. 211- 223.

[20] J. Brouver and H. Anderson, "Water Holding Capacity of Ironstone Gravel in a Typical Plinthoxeralf in Southeast Australia," Soil Science Society of America Journal, Vol. 64, No. 5, 2000, pp. 1603-1608. doi:10.2136/sssaj2000.6451603x

[21] R. Walczak, E. Rovdan and B. Witkowska-Walczak, "Water Retention Characteristics of Peat and Sand Mixtures," International Agrophysics, Vol. 16, No. 2, 2002, pp. 161165.

[22] T. Włodarczyk, W. Stępniewski, M. Brzezińska and G. Przywara, "Impact of Different Aeration Conditions on the Content of Extractable Nutrients in Soil," International Agrophysics, Vol. 22, No. 4, 2008, pp. 371-375.

[23] Z. Stępniewska, A. Wolińska and R. P. Bennicelli, "In- fluence of Soil Water Potential on Microdiffusion of Oxygen in the Eutric Cambisol," Acta Agrophysica, Vol. 84, No. 1, 2003, pp. 145-152.

[24] A. M. Gajda, "Effect of Different Tillage Systems on Some Microbiological Properties of Soils under Winter Wheat," International Agrophysics, Vol. 22, No. 1, 2008, pp. 201208.

[25] A. M. Gajda, "Microbial Activity and Particulate Organic Matter Content in Soils with Different Tillage System Use," International Agrophysics, Vol. 24, No. 2, 2010, pp. 129137.

[26] N. Jedidi, "Microbial Biomass in a Soil Amended with Different Types of Organic Wastes," Waste Management Research, Vol. 22, No. 2, 2004, pp. 293-299. doi: $10.1177 / 0734242 \mathrm{X} 04043930$

[27] P. Nannipieri, L. Badalucco, L. Landi and G. Pietramellara, "Measurements in Assessing the Risk of Chemicals to the Soil Ecosystem," In: J. T. Zelikoff, Ed., Ecotoxicology: Responses, Biomarkers and Risk Assessment, SOS Publications, New York, 1997, pp. 507-534.

[28] M. C. Fisk and T. J. Fahey, "Microbial Biomass and Nitrogen Cycling Responses to Fertilization and Litter Removal in Young Northern Hardwood Forests," Biogeochemistry, Vol. 53, No. 2, 2001, pp. 201-223. doi:10.1023/A:1010693614196

[29] K. Mohammadi, "Soil Microbial Activity and Biomass as Influenced by Tillage and Fertilization in Wheat Production," American-Eurasian Journal of Agriculture and Environmental Sciences, Vol. 10, No. 3, 2011, pp. 330-337.

[30] S. Lerat, L. England, J. Klironomos, P. Pauls, C. Swanton and J. T. Trevors, "Real-Time Polymerase Chain Reaction Detection of the Transgenes for Roundup Ready Corn and Soybean in Soil Samples," Journal of Agricultural and Food Chemistry, Vol. 53, No. 5, 2005, pp. 1337-1342. doi:10.1021/jf048830+

[31] L. Sagova-Mareckova, L. Cermak, J. Novotna, K. Plhackova, J. Forstova and J. Kopecky, "Innovative Methods for Soil DNA Purification Tested in Soils with Widely Differing Characteristics," Applied and Environmental Microbiology, Vol. 74, No. 9, 2008, pp. 2902-2907. doi:10.1128/AEM.02161-07

[32] L. I. Singh and P. S. Yadava, "Spatial Distribution of Microbial Biomass in Relation to Land-Use in Subtropical Systems of North-East India," Tropical Ecology, Vol. 47, No. 1, 2006, pp. 63-70.

[33] E. V. Blagodatskaya, O. S. Khokhlova and S. A. Blagodatskii, "Extractable Microbial DNA Pool and Microbial Activity in Paleosols of Southern Urals," Microbiology, Vol. 72, No. 6, 2003, pp. 750-755. doi:10.1023/B:MICI.0000008380.57233.9e

[34] M. Hartmann, B. Frey, R. Kölliker and F. Widmer, "SemiAutomated Genetic Analyses of Soil Microbial Communities: Comparison of T-RFLP and RISA Based on Descriptive and Discriminative Statistical Approaches," Journal of Microbiological Methods, Vol. 61, No. 3, 2005, pp. 349-360. doi:10.1016/j.mimet.2004.12.011 